\title{
Bone from blood: Characteristics and clinical implications of circulating osteogenic progenitor (COP) cells
}

\author{
Jack Feehan $^{\text {a,b }}$, Moustapha Kassemc, Robert J. Pignolod, Gustavo Duque a,b * \\ ${ }^{a}$ Australian Institute for Musculoskeletal Science (AIMSS), University of Melbourne and \\ Western Health, St Albans, VIC, Australia \\ ${ }^{b}$ Department of Medicine - Western Health, University of Melbourne, VIC, Australia \\ ${ }^{c}$ Molecular Endocrinology Laboratory (KMEB), Department of Endocrinology, Odense \\ University Hospital \& University of Southern Denmark, Odense, Denmark; Department of \\ Cellular and Molecular Medicine, The Novo Nordisk Foundation Center for Stem Cell Biology \\ (DanStem), University of Copenhagen, Copenhagen, Denmark \\ d Department of Medicine, Mayo Clinic School of Medicine, Mayo Clinic, Rochester, MN, \\ United States.
}

Running title: Clinical implications of COP cells

* Corresponding Author

Address correspondence to Prof. Gustavo Duque, MD, Ph.D., FRACP, FGSA

ORCID: 0000-0001-8126-0637

The Australian Institute for Musculoskeletal Science (AIMSS), the University of Melbourne

This is the author manuscript accepted for publication and has undergone full peer review but has not been through the copyediting, typesetting, pagination and proofreading process, which may lead to differences between this version and the Version of Record. Please cite this article as doi: $10.1002 / \mathrm{jbmr} .4204$

This article is protected by copyright. All rights reserved. 
and Western Health, 176 Furlong Road, St. Albans, VIC, Australia 3021.

E-mail: gustavo.duque@unimelb.edu.au

Abstract: Circulating osteogenic progenitor (COP) cells are a population of cells in the peripheral blood with the capacity for bone formation, as well as broader differentiation into mesoderm-like cells in vitro. While some of their biological characteristics are documented in vitro their role in diseases of the musculoskeletal system remains yet to be fully evaluated. In this review, we provide an overview of the role of COP cells in a number of physiological and pathological conditions, as well as identify areas for future research. In addition, we suggest possible areas for clinical utilization in the management of musculoskeletal diseases.

Key Words: Circulating osteogenic precursor cells; COP cells; Osteoporosis; Heterotopic ossification; Fracture; Vascular Calcification; Frailty.

This article is protected by copyright. All rights reserved. 


\section{Introduction}

Circulating osteogenic precursor (COP) cells are a relatively recently discovered population of progenitor cells which have been implicated to play a role in the pathogenesis of several cardiovascular, metabolic, geriatrics, and musculoskeletal diseases. They are described broadly as a population of cells within the peripheral circulation with the capacity for osteoblastic differentiation though multiple studies have demonstrated that they can also differentiate into other (mesenchymal) mesoderm-like cells -such as adipocytes, myocytes and chondrocytes. ${ }^{(1,2)}$ This capacity has logically led them to be considered as circulating surrogates of the bone marrow mesenchymal stem and progenitor cell (MPC) population, due to their expression of markers such as CD73, CD90 and CD105 by some reports, and also considered as in transit to sites of tissue regeneration e.g. physiological conditions as in normal pubertal development or bone remodeling, or pathological conditions, such as in tissue injury or musculoskeletal diseases. However, recent studies identified COP cells with a hematopoietic phenotype CD45+, CD34+ and $\mathrm{CD} 14+{ }^{(3)}$ which are not expressed by cultured bone marrow MPCs. ${ }^{(4)}$

This article is protected by copyright. All rights reserved. 
In a recent review, ${ }^{(3)}$ two distinct populations of COP cells were described, one expressing the hematopoietic lineage markers mentioned above, and the other MPC-like, not expressing CD45, CD14 and CD34. Irrespective of their origin, there is a small but growing body of research surrounding their behavior in both pathological and physiological settings, however differences in methodologies and criteria used for their characterization have limited the advancement of the field. ${ }^{(3)}$ Herein, we analyze and synthesize the literature on the biology of COP cells and their role in physiological and pathological processes, and identify areas which hold potential for clinical exploitation, whether it be in diagnosis, monitoring or treatment. Finally, we identify areas for future research allowing a more targeted approach in determining the role of COP cells in vivo, and their relationship to diseases in a number of systems.

\section{Blood borne osteoblasts: A historical perspective}

The idea of a circulating cell which could form osteoblasts has existed since the end of the $19^{\text {th }}$ century, with the discovery of osteoclasts in the circulation in the 1870 's. While the theory was attractive, no such cell was able to be identified, and so investigators turned elsewhere to attempt to identify the origins of the osteoblasts on the bone surface. Upon the discovery of bone marrow cells with osteogenic potential by Friedenstein, ${ }^{(5)}$ interest renewed in circulating progenitors as a means to describe how osteoblasts were regenerated in the fracture setting, particularly when the fracture was not adjacent to the 
red bone marrow. COP cells remained elusive until 1997, when they were isolated from the blood of breast cancer patients who had undergone GM-CSF and G-CSF mediated hematopoietic stem cell (HSC) mobilization. ${ }^{(6)}$ Despite these factors being used to mobilize CD34+ HSCs, the COP cells described did not express any hematopoietic markers, instead bearing the markers of MPCs. Similar cells were identified in the blood of healthy individuals shortly after, ${ }^{(7)}$ and their capacity for ex vivo ossification confirmed. ${ }^{(2)}$ Given the similarities between these cells and the bone marrow MPC, they were quickly described as being a surrogate which was in transit to a site of bone formation. Shortly afterward however, the hematopoietic COP cell population was identified in the blood of health individuals. ${ }^{(1,8)}$ Mesenchymal progenitors with hematopoietic markers had been identified earlier in the bone marrow, with Long et al showing the non-adherent bone marrow fraction having osteogenic capacity but expressing CD34, in direct contradiction with the common understanding of mesenchymal progenitors. ${ }^{(9,10)}$

\section{COP cell biology}

The literature surrounding the biological characteristics of COP cells is complex and often contradictory, particularly regarding their ontology. Two populations of COP cells have been identified - one bearing cell surface antigens of the hematopoietic lineage, ${ }^{(1,11)}$ and another seemingly identical to the bone marrow MPC. ${ }^{(2,12)}$ Perhaps explaining this discrepancy, Suda et al ${ }^{(13)}$ demonstrated that freshly isolated COP cells lose hematopoietic markers soon after introduction into culture. Both populations are shown to express markers associated with

This article is protected by copyright. All rights reserved. 
bone formation, such as osteocalcin (OCN), alkaline phosphatase (ALP) and type one collagen (Col1). However, independent of their lineage, some aspects of their underlying biology have been described in both populations. Generally, COP cells have been analyzed via techniques such as flow cytometry and immunohistochemistry for these markers, though a small number of studies have placed peripheral blood mononuclear cells (PBMCs) in cell culture and used plastic adherence to isolate the cells. ${ }^{(1,7)}$ Others have depleted the hematopoietic fraction of the blood through via approaches such as fluorescence activated cell sorting and cultured the COP subsets, again using plastic adherence as a secondary selection measure. ${ }^{(14)}$ COP cells of both lineages appear to originate from the bone marrow, as demonstrated in both parabiotic and bone marrow transplantation models, ${ }^{(15)}$ although one study did not support this finding. ${ }^{(16)}$ The strongest evidence for a bone marrow origin of COP cells in humans comes from analysis of peripheral blood mononuclear cells from recipients of sex-mismatched bone marrow transplantations. ${ }^{(13)}$

The number of COP cells in the peripheral circulation is generally low, ${ }^{(13)}$ however there are some differences between the lineages. The hematopoietic COP cell population seems to be present in an almost steady state in health, ${ }^{(17)}$ but shows an increase in number in states of accelerated bone growth such as puberty and fracture healing. ${ }^{(8)}$ The COP cells with an MPClike phenotype appears to only be present in the blood of individuals in states of bone repair. ${ }^{(12)}$ This suggests that both populations undergo mobilization in response to conditions of increased osteoblastic demand and recruitment, however the role of the baseline population of hematopoietic COP cells is unclear. This mobilization has been linked 
most strongly to the C-X-C receptor type 4 (CXCR4)/ C-X-C motif chemokine 12 (CXCL12) (historically known as SDF1) axis in both hematopoietic and non-hematopoietic populations. ${ }^{(18,19)}$ Additionally, COP cells have been shown to increase in response to a range of tissue factors related to injury and inflammation, such as substance $P,{ }^{(20)}$ hypoxia ${ }^{(21)}$ and growth factors, ${ }^{(6)}$ possibly suggesting a role in general tissue regeneration processes.

In terms of their capacity for differentiation, COP cells of both lineages have been shown to differentiate into all four typical mesoderm-like cells of bone, fat, muscle and cartilage tissues and the efficiency for differentiation was more enhanced in COP cells with MPC-like phenotype. ${ }^{(1,2)}$ A likely explanation is the already established isolation and culture methods for MPCs being more easily transferable, while effective in vitro expansion of the COP cells with a hematopoietic phenotype remains a challenge. ${ }^{(3)}$ Other markers have been used as a proxy for their state of maturation. Researchers have identified the expression of the markers CD34 and CD146 as identifying less mature, more 'stem-like' cells, particularly in the hematopoietic population, correlating a decrease in these surface antigens with increased maturity toward terminal differentiation. ${ }^{(22,23)}$ Figure 1 shows a summary of the known background biology, and a putative lineage for both populations of COP cells.

\section{COP cells: harbingers of altered bone formation}

Perhaps unsurprisingly, the largest part of the literature on COP cells is focused on pathology involving abnormal bone formation e.g. abnormal or ectopic ossification or

This article is protected by copyright. All rights reserved. 
demineralization. While COP cells have been shown to differentiate into the full spectrum of mesoderm-like cells, there are very no studies demonstrating their role in pathological processes of tissues such as muscle or cartilage damage. The literature surrounding the role of COP cells in specific pathologies can be largely divided into states of abnormal bone formation, or accelerated catabolism of musculoskeletal tissues.

\section{COP cells in states of bone anabolism and abnormal calcification.}

There are a number of pathologies of accelerated bone formation and physiological responses to injury in which COP cells have been theorized to play a role, summarized in figure 2. These include fracture, vascular calcification, and several subtypes of heterotopic ossification (table 1).

\section{(i) Fracture healing}

COP cells were first proposed as a mechanism for the healing of fractures, particularly in sites that are not directly adjacent to red bone marrow. COP cells provided a feasible mechanism for the replenishment of osteoblasts during healing of these fractures. This hypothesis drove the earliest research in the field and continues to provide new discoveries in the role of COP cells in fracture repair.

\section{Fracture}

\begin{tabular}{cccccc}
\hline Study & $\begin{array}{c}\text { COP cell } \\
\text { phenotype }\end{array}$ & $\begin{array}{c}\text { Markers } \\
\text { Studied }\end{array}$ & Study & $\begin{array}{c}\text { COP cell } \\
\text { phenotype }\end{array}$ & Markers Studied \\
\hline $\begin{array}{l}\text { Kumagai et } \\
\text { al., 2008 }\end{array}$ & Unknown & ALP+ & $\begin{array}{c}\text { Kelly et al., } 2018 \\
\text { (33) }\end{array}$ & Hematopoietic & $\begin{array}{c}\text { CD34+ } \\
\text { OCN+ }\end{array}$
\end{tabular}

This article is protected by copyright. All rights reserved. 


\begin{tabular}{|c|c|c|c|c|c|}
\hline $\begin{array}{l}\text { Kumagai et } \\
\text { al., } 2012^{(26)}\end{array}$ & Unknown & $\begin{array}{c}\text { CXCR4+ } \\
\text { ALP+ }\end{array}$ & Alm et al., 2010 & $\begin{array}{c}\text { Non- } \\
\text { Hematopoietic }\end{array}$ & $\begin{array}{c}\text { CD105+ CD73+ } \\
\text { CD90+ CD45- } \\
\text { CD14- }\end{array}$ \\
\hline $\begin{array}{c}\text { Iwakura et al., } \\
2013^{(27)}\end{array}$ & Unknown & $\begin{array}{c}\text { Plastic } \\
\text { Adherence }\end{array}$ & Wan et al., 2006 & Unknown & Plastic Adherence \\
\hline $\begin{array}{l}\text { D'Amelio et } \\
\text { al., } 2010{ }^{(28)}\end{array}$ & Unknown & $\begin{array}{l}\text { OCN+ } \\
\text { ALP+ }\end{array}$ & $\begin{array}{l}\text { Matsumoto et } \\
\text { al., } 2006^{(36)}\end{array}$ & Hematopoietic & $\begin{array}{l}\text { CD34+ } \\
\text { OCN+ }\end{array}$ \\
\hline $\begin{array}{l}\text { Sicco et al., } \\
2018^{(31)}\end{array}$ & $\begin{array}{c}\text { Non- } \\
\text { hematopoietic }\end{array}$ & $\begin{array}{c}\text { Lin- CD45- } \\
\text { BST2+ }\end{array}$ & $\begin{array}{l}\text { Mifune et al., } \\
2008^{(37)}\end{array}$ & Hematopoietic & $\begin{array}{l}\text { CD34+ } \\
\text { OCN+ }\end{array}$ \\
\hline $\begin{array}{l}\text { Ritz et al., } \\
2014^{(32)}\end{array}$ & Hematopoietic & $\begin{array}{l}\text { CD45+ } \\
\text { CD34+ }\end{array}$ & & & \\
\hline
\end{tabular}

\section{Heterotopic Ossification}

\begin{tabular}{|c|c|c|c|c|c|}
\hline $\begin{array}{l}\text { Yang et al., } \\
2011{ }^{(42)}\end{array}$ & Unknown & $\begin{array}{l}\text { Plastic } \\
\text { Adherence }\end{array}$ & $\underset{(44)}{\text { Egan et al., } 2018}$ & Hematopoietic & CD45+ Col1+ \\
\hline $\begin{array}{l}\text { Otsuru et al., } \\
2007 \text { (43) }\end{array}$ & Unknown & $\begin{array}{c}\text { Plastic } \\
\text { Adherence } \\
\text { ALP+ OCN+ }\end{array}$ & $\underset{(13)}{\text { Suda et al, } 2009}$ & Hematopoietic & CD45+ Col1+ \\
\hline $\begin{array}{c}\text { Otsuru et al., } \\
2008^{(19)}\end{array}$ & $\begin{array}{c}\text { Non- } \\
\text { hematopoietic }\end{array}$ & $\begin{array}{c}\text { CXCR4+ } \\
\text { CD44+ CD45- }\end{array}$ & & & \\
\hline \multicolumn{6}{|c|}{ Vascular calcification } \\
\hline $\begin{array}{l}\text { Egan et al., } \\
2011 \text { (11) }\end{array}$ & Hematopoietic & $\begin{array}{l}\text { CD45+ } \\
\text { Col1+ }\end{array}$ & $\underset{\text { Pal et al., }}{2011}$ & Unknown & $\mathrm{OCN}+$ \\
\hline $\begin{array}{c}\text { Fadini et al., } \\
2011\end{array}$ & Hematopoietic & $\begin{array}{c}\text { CD45+ CD14+ } \\
\text { OCN+ ALP+ }\end{array}$ & $\begin{array}{l}\text { Takahashi et al., } \\
\qquad 2016^{(52)}\end{array}$ & Hematopoietic & $\mathrm{CD} 34+\mathrm{KDR}+$ \\
\hline Pal et al., 2010 & Unknown & $\mathrm{OCN}+$ & $\begin{array}{c}\text { Wang et al., } \\
2014 \text { (53) }\end{array}$ & $\begin{array}{c}\text { Non- } \\
\text { hematopoietic }\end{array}$ & $\begin{array}{c}\text { CD29+ Sca1+ } \\
\text { Nestin+ CD11b- } \\
\text { CD45- }\end{array}$ \\
\hline
\end{tabular}

Table 1. Summary of studies on COP cells in states of bone formation. ALP: Alkaline Phosphatase, CXCR4: C-X-C chemokine receptor 4, OCN: Osteocalcin, Lin: Lineage, BST2: Bone marrow stromal cell antigen 2, Sca1: Stem cell antigen 1, Col1: Collagen type 1.

COP cells have been shown to home into sites of fracture healing in a parabiotic mouse model whereby transgenic mice expressing green fluorescent protein $(\mathrm{GFP}+)$ are surgically conjoined to wild type (WT) mice so as to share circulation. Fractures induced in the WT

This article is protected by copyright. All rights reserved. 
mice show presence of GFP+ cells at the site of bone healing, demonstrating that circulating cells migrate to the site of fractures and engraft withing the callus. The GFP positive cells made up $5.4 \%$ of the cells in the fracture environment, compared to $1.7 \%$ in non-fractured controls. In addition, $85.3 \%$ of these cells were demonstrated to express ALP. Hence, it was suggested that the GFP+ cells were contributing to bone formation at the fracture site. ${ }^{(15)}$ While this study suggests that circulating cells have the capacity to migrate from the bone marrow to a site of fracture and contribute to the formation of a callus, the specific identity and role of the cells studied remains unclear.

There are a number of cell types known to exist in the circulation which home to sites of injury such as monocytes and lymphocytes, both of which have been shown to express AP in various conditions. ${ }^{(24,25)}$ Another model of parabiosis was used to show that the use of low intensity pulsed ultrasound (LIPUS) caused an increase in the migration of COP cells to a fracture site, with a resulting increase in the area of the callus. ${ }^{(26)}$ After the surgical union of one GFP+ animal to a GFP- partner, fracture was induced in the wild type animal. At 2 and 4 weeks, it was shown that GFP+ cells had migrated to the fracture site, and had increased their expression of AP, in agreement with previous studies. They also showed that there was an increase in the area of the callus at both timepoints in the mice treated with LIPUS, and that there was an increase in the number of cells expressing CXCL12 and CXCR4 in the experimental animals. ${ }^{(26)}$ In another animal model, COP cells were obtained from both the venous and arterial circulation in the week following an induced fracture and compared to 
bone marrow MPCs in their ability to form colonies. The MPCs and COP cells from both arterial and venous blood had increased colony formation efficiency (CFE) in the week following an induced fracture, and all had near identical morphology and behavior in culture. It was also shown that the cells obtained from the bone marrow had the highest CFE, followed closely by those from the arterial circulation, which in turn had a much higher capacity for colony formation than the venous COP cells. ${ }^{(27)}$ These findings suggested that COP cells circulate in response to fracture, but circulate in the arterial circulation in greater numbers, perhaps lending insight into their rarity in other studies - all of which sample venous blood in their experiments. This could suggest that the cells are mobilized into the arterial blood in response to injury, homing to the site of injury via factor gradient chemotaxis and undergoing extravasation and therefore leading to a differential between COP cell number between the two circulations.

In contrast, another study showed that the number of COP cells did not change during the early stage of fracture healing, instead suggesting that the cells mature and differentiate, rather than proliferate in response to bone injury. Blood isolated from patients with acute fractures at presentation to the emergency department, and again 15 days later showed no change in the number of COP cells (defined as circulating cells expressing OCN and ALP). ${ }^{(28)}$ There was however, an increase in the maturation state of the cells with an inverse relationship to transforming growth factor beta 1 (TGF 1$)^{.(28)}$ TGF $\beta 1$ is an important cytokine involved in a number of processes including cell proliferation and growth, and can 
act as both a powerful inhibitor or stimulator of cell replication. ${ }^{(29,30)}$ The study suggests that in fact, COP cells may not increase in number, but undergo a process of maturation in response to fracture, and that TGF $\beta 1$ is a main contributor in this process. Although in these studies the number of COP cells was not shown to increase in response to fracture, other studies have demonstrated the opposite. ${ }^{(31-33)}$

A population of 'circulating healing' cells with a pattern of marker expression very similar to bone marrow MPCs was shown to be present in increased numbers in response to factors released following fracture. They were also shown to home to, and engraft within, the site of bone injury in mice. ${ }^{(31)}$ Similarly, progenitor cells expressing the endothelial and stem cell marker CD34, and the pan-hematopoietic surface antigen CD45 were shown to mobilize into peripheral blood, in patients will severe traumatic fractures. ${ }^{(32)}$ The numbers of these cells in the circulation were shown to increase as much as 12 -fold in the week after injury and their levels correlated with clinical parameters such as the injury severity score. Whilst the cells in these studies were named as "circulating healing cells", and "endothelial and angiogenic precursors" respectively, they fit within criteria commonly used to describe COP cells. Moreover, in mice, $\mathrm{CD} 34+/ \mathrm{OCN}+\mathrm{COP}$ cells have been shown to peak at 3 weeks postfracture and are present at the fracture site throughout the callus. Thus, the authors suggest that it is likely that COP cells directly contribute to fracture healing. ${ }^{(33)}$ Plastic adherent cells identical in marker expression to bone marrow MPCs (CD105+/ CD73+/CD90+/CD45-/CD14-) were identified in the blood of $22 \%$ of older hip fracture patients and $46 \%$ of younger fracture patients, suggesting that they are mobilized in response to bone injury as well as 
indicating an impaired response in older patients when compared to their younger peers. ${ }^{(12)}$ Interestingly, in the same study these cells were not present in an aged matched population of patients with hip osteoarthritis treated with total hip arthroplasty, suggesting that surgically induced bone injury does not stimulate their mobilization in the circulation. This could be explained by a number of other differences between the intervention groups such as post-operative heterotopic ossification prophylaxis, or time variables relating to surgery, as it is challenging to hypothesize that surgically induced bone injury is a smaller signal for COP circulation than fracture. These studies provide evidence for a role for COP cells in the formation and ossification of the fracture callus.

COP cells have also been evaluated for therapeutic use in animal models of fracture. Criticalsized defects (that is, large fractures with significantly reduced healing potential) ${ }^{(34)}$ were created in the ulna of New Zealand white rabbits, followed by surgical implantation of skelite implants treated with bone marrow MPCs or COP cells. It was noted that both MPC and COP cells treated implants enhanced the closure of the defect when compared to skelite without cellular elements, suggesting that peripheral blood cells may be a comparable cellular therapy in fracture healing compared to the more commonly used MPCs. ${ }^{(35)}$ Similarly, CD34+ cells ( $20 \%$ of which also express OCN) isolated from the peripheral blood have been shown to promote angiogenesis and osteogenesis on radiographic and histomorphometric analysis in murine fracture models either via systemic infusion, ${ }^{(36)}$ or when implanted into a defect on a bioscaffold. ${ }^{(37)}$

This article is protected by copyright. All rights reserved. 
Overall, the available studies suggest COP cells are likely to be mobilized in response to fracture, ${ }^{(12,32)}$ home to the site of injury, ${ }^{(15,27)}$ undergo a maturation process, ${ }^{(28)}$ and contribute to the osteogenesis and angiogenesis required for fracture healing. ${ }^{(35,36)}$ Whilst these studies demonstrate some basic parameters of COP cell behavior during fracture healing, there is still very little known about these cells. Firstly, the identity of the specific cells studied remains unclear, with a range of different markers used to characterize different cell lineages. Specifically defined populations, their relationships, and their exact roles in the process of healing needs to be explored further. Secondly, specific mechanistic evidence regarding the roles of COP cells are lacking. While it has been suggested that COP cells may mature into osteoblasts and contribute to fracture healing by direct osteogenesis, one study has shown this not to be the case. A novel triple transgenic mouse model used to identify cells that expressed CD45 at any time in their specific lifespan was studied to evaluate the behavior of these cells following fracture. It was demonstrated that while CD45+ cells migrated to and were present at the site of bone injury, they did not differentiate into osteoblasts like their non-hematopoietic counterparts. ${ }^{(18)}$ This may suggest that COP cells play a synergistic role in bone healing, rather than directly ossifying the callus; however, conflicting evidence exists. MPCs are known to secrete an array of growth factors and immunomodulatory cytokines and it is possible that these factors could contribute to the physiological and therapeutic effects of COP cells in fracture healing. ${ }^{(38)}$ Thus, it is possible that COP cells have a similar function in vivo, although further studies are required.

This article is protected by copyright. All rights reserved. 
COP cells have been shown to home to sites of injury via the C-X-C receptor type 4 (CXCR4) CXCL12 axis, ${ }^{(19)}$ although it is unknown how they respond to many other chemotactic and inflammatory factors. It has been shown that CXCL12 expression is increased in fractured bone and damaged periosteum, making this a likely mediator of their homing response. $(39,40)$ While fracture repair is by far the most well researched area of COP cells biology, states of pathological bone formation and abnormal calcification have also been explored, such as, heterotopic ossification and vascular calcification.

\section{(ii) Heterotopic Ossification}

Heterotopic ossification $(\mathrm{HO})$ is the pathological process of bone formation in non-skeletal tissue and can be acquired or hereditary. The vastly more common acquired form occurs after trauma or injury, usually of the nervous or musculoskeletal systems. There are several hereditary forms, including an autosomal dominant genetic disorder known as fibrodysplasia ossificans progressiva (FOP) caused by missense mutations in the in the gene for ACVR1/ALK2, encoding Activin A receptor type I/Activin-like kinase 2, a bone morphogenetic protein (BMP) type I receptor. ${ }^{(41)}$ COP cells may seed sites of injury and inflammation which precede the formation of endochondral bone identified in both genetic and non-genetic forms of $\mathrm{HO}$.

Several animal models of BMP-mediated HO have been used to identify whether COP cells play a role in the formation of ectopic bone. One study showed that the combination of

This article is protected by copyright. All rights reserved. 
PBMCs and BMP-2 in a pellet implanted into athymic mice led to increased osteogenesis when compared to either alone. ${ }^{(42)}$ In another study, GFP+ bone marrow was transplanted into C57BL/6 mice after lethal-dose irradiation, followed by implantation of a BMP-2 laden pellet into the muscle tissue. This induced the ossification of the pellet, with an accumulation of GFP+ bone marrow cells within the newly formed bone after 3 weeks. ${ }^{(43)}$ This suggests that BMP signaling can recruit cells to the site of osteogenesis from the bone marrow; however, bone marrow forms in mature $\mathrm{HO}$ and the presence of GFP+ bone marrow cells by itself does not necessarily implicate COP cells in the ectopic bone formation. A follow up study by the same authors suggested that the CXCR4/CXCL12 axis was a key mediator of COP cell migration. In the same BMP-2 pellet model of $\mathrm{HO}$, cells expressing CXCR4 were shown to migrate to the site of osteogenesis. Treatment with an antibody targeting CXCR4 caused a significant decrease in this migration, providing evidence for its role in COP cell migration. ${ }^{(19)}$ The COP cells in these two studies did not express hematopoietic markers however other reports have implicated a CD45+ population in $\mathrm{HO}$.

In a study of acquired $\mathrm{HO}, \mathrm{CD} 45+/ \mathrm{Col} 1+\mathrm{COP}$ cells were shown to be present in bone lesions acquired from donors who had suffered cerebrovascular accident, spinal cord injury, traumatic brain injury, non-neurological trauma and those who had undergone joint arthroplasty. ${ }^{(44)}$ Previously it was shown that acquired $\mathrm{HO}$ occurs in six distinct histological stages: (1) perivascular lymphocytic infiltration, (2) lymphocytic migration into soft tissue, (3) reactive fibroproliferation, (4) neovascularity, (5) cartilage formation and (6)

This article is protected by copyright. All rights reserved. 
endochondral bone formation. ${ }^{(45)}$ COP cells were shown to be present at the early stage of fibroproliferative lesions that precede $\mathrm{HO}$, suggesting both a role in the pathological tissue mechanism, and a capacity to migrate to sites of injury in vivo.

COP cells have also been shown to be involved in the pathogenesis of FOP. FOP is characterized by fluctuations in disease activity, and blood from patients with active FOP has significantly higher numbers of COP cells compared to healthy subjects, or those with inactive disease. ${ }^{(13)}$ Interestingly, one patient with clinically inactive FOP also had the highest level of COP cells that was predictive for a period of high disease activity a week later. It was also shown that COP cells were able to form bone both in vitro, and in an in vivo murine model of HO. Finally, bone marrow transplantation in FOP does not diminish disease activity. ${ }^{(46)}$ Thus, if COP cells are involved in $\mathrm{HO}$ formation, it is secondary to their altered regulation, rather than by intrinsic aberrations within the cells themselves by FOP. This study provides some conceptual evidence of COP cells involvement in predicting and pathogenesis of $\mathrm{HO}$, as they appear to both indicate and precede outbreaks of ossification.

Whilst promising, these findings require significant verification, and diagnostic or prognostic cut points need to be established. Although it appears that COP cells contribute to the pathogenesis of both forms of $\mathrm{HO}$, much remains unknown. There is as yet no true mechanistic evidence for the tissue reprogramming that leads to a chondrogenic versus myogenic fate after muscle injury, although an endochondral anlagen is a requirement for 
HO formation that may be contributed to by COP. Additionally, only the hematopoietic lineage COP cells have been examined in $\mathrm{HO}$ - no studies have explored a potential role of the mesenchymal COP cells in ectopic bone formation. COP cells are a logical contributor to pathologies featuring ossification distant to the skeleton, however significantly more research is required to explore this fully, as well as to identify future clinical utility of targeting COP cells in the management of these conditions of aberrant ossification.

\section{(iii) Vascular Calcification}

Vascular calcification is a common occurrence in older adults and is strongly associated with poorer cardiovascular health outcomes. ${ }^{(47)}$ Interestingly, vascular calcification correlates with a range of other bone and metabolic disorders such as osteoporosis and diabetes further suggesting a link between the physiologies of the skeletal and vascular systems. ${ }^{(48)}$ Due to their demonstrated role in both extra-skeletal osteogenesis, and their hematovascular-mesenchymal characteristics, several studies have investigated the role of COP cells in the pathogenesis of vascular calcification.

COP cells have been shown to be present in a number of common sites of vascular calcification. COP cells characterized as CD45+/Col1+ were identified in areas of mineralization in archived aortic valve specimens. ${ }^{(11)}$ Furthermore, an increase in COP cells have been suggested to contribute to the development of vascular calcification in diabetic patients. Circulating cells expressing CD45, CD14, OCN and ALP are increased in number in

This article is protected by copyright. All rights reserved. 
diabetic patients, and have also been identified within calcified atherosclerotic plaques, ${ }^{(49)}$ suggesting that COP cells are somehow implicated in the pathological process of vascular calcification, though it remains unclear as to whether they play a causative role.

In addition to being correlated with the incidence of vascular calcification, it has also been shown that COP cells are positively associated with the severity of the disease. In one study using a murine model of vascular calcification involving osteoprotegerin (OPG) deficient mice (which develop moderate vascular calcification), the number of COP cells correlated to the amount of extractable calcium found in the aortas of mice. Moreover, the severity of disease in OPG deficient mice is increased by the addition of calcitriol, and the association with COP cells remains consistent. What role the addition of calcitriol played in the physiology of COP remains unclear however, and while interesting, these findings are unable to identify cause and effect, with only correlational data presented. In the same study it was shown that in humans with peripheral arterial disease, an association between the number of circulating $\mathrm{OCN}+$ cells and the severity of arterial calcification as measured by computed tomographic angiogram. ${ }^{(50)}$ Similarly, the number of COP cells in the peripheral circulation is associated not only with the severity of aortic calcification, but with the level of stem cell mobilizing cytokines, such as CXCL12 and granulocyte colony stimulating factor (GCSF). In both humans and mice with more severe calcification, higher levels of CXCL12 and G-CSF, as well as OCN+ COP cells were present. ${ }^{(51)}$

This article is protected by copyright. All rights reserved. 
Another human study linked the severity of aortic calcification, with COP cell number. Interestingly, this study was investigating CD34+/KDR+ endothelial progenitor cells (EPCs), which co-expressed OCN, further complicating the picture of the mesenchymal-vascular lineages. Patients with severe aortic stenosis and coronary heart disease had lower numbers of non-osteogenic EPCs, but higher numbers of OCN+ EPCs, suggesting an osteogenic shift in the circulating progenitor pool. Another study has suggested that dysregulation of circulating micro-RNA (miRNA) could be the mechanism for the osteogenic phenotype of the circulating progenitor pool. Patients with aortic calcification had significantly higher CD34$/ \mathrm{CD} 133+/ \mathrm{KDR}+/ \mathrm{OCN}+\mathrm{COP}$ cell numbers, and that this correlated with the circulating levels of seven osteogenesis related miRNAs. Treatment of PBMCs in vitro with six of these miRNAs (MiRNAs 106a, 148a, 204, 211, 31 \& 424) caused an increase in the expression of OCN, while conversely the seventh (miRNA 30c) caused a decrease in its expression. ${ }^{(52)}$ These results suggest a possible regulatory mechanism behind the changes seen in COP cell behaviour in pathological settings, however the source of these miRNAs is yet to be determined. The common inflammatory marker TGF $\beta$ has also been implicated as a mediator between COP cells and vascular calcification. In a low-density lipoprotein receptor deficient (Idlr-) animal model of vascular calcification, a high fat diet was used to stimulate the development of the disease. These mice were parabiotically paired with transgenic mice in which nestin ${ }^{+}$mesenchymal lineage cells were fluorescently labelled via GFP. Labelled COP cells from the transgenic animal were present in the circulation in increased numbers and homed to sites of vascular calcification. To test the role of TGF $\beta$ in this process, a

This article is protected by copyright. All rights reserved. 
neutralizing antibody, and an enzyme inhibitor of TGF $\beta$ receptor 1 kinase were utilized and both antagonized the COP cell migration. ${ }^{(53)}$

While this evidence suggests that COP cells have a role in vascular calcification, much remains uncertain. It appears that COP cells, particularly those expressing hematopoietic and vascular markers such as CD45 and CD34 contribute to the calcification of atherosclerotic plaques and aortic valves at some level, and that they correlate to the severity of the calcification, however it is still unknown what causes this process. Whether the COP cells are attracted to sites of vascular injury, and inflammation and so infiltrate the vessel and calcify it, or whether they underlie the disease at a more mechanistic level remains to be demonstrated. It appears to be mediated at least partially by stem cell mobilizing factors, inflammatory mediators from atherosclerotic vessels, and osteogenic miRNAs, although the full mature of these relationships in vivo is unknown. Finally, the role of the non-hematopoietic COP cell population has yet to be determined in the calcification of vessels, possibly due to the disease failing to mobilize them from the marrow.

\section{States of bone and muscle loss}

\section{Osteoporosis and Frailty}

The evidence presented thus far has centered around pathologies or states of increased bone formation, but COP cells have also been identified has having a potential role in the pathogenesis of osteoporosis and frailty (figure 3). Osteoporosis, the reduced maintenance

This article is protected by copyright. All rights reserved. 
of bone mineral density (BMD) associated with age, is a growing challenge to the global health care system due to the aging population worldwide. ${ }^{(54)}$ Osteoporosis is also a secondary complication of many other common endocrine and metabolic diseases such as diabetes and hypothyroidism. COP cells have been studied as having a possible role in the underlying mechanism for the disease, based on the hypothesis that their dysregulation may cause a decrease in ongoing ossification over the life span. Table 2 summarizes the evidence surrounding COP cells in osteoporosis and frailty.

\section{Primary Osteoporosis}

\begin{tabular}{|c|c|c|c|c|c|}
\hline Study & COP cell phenotype & $\begin{array}{c}\text { Markers } \\
\text { Studied }\end{array}$ & Study & $\begin{array}{c}\text { COP cell } \\
\text { phenotype }\end{array}$ & Markers Studied \\
\hline$\underset{\text { (55) }}{\text { Pirro et al., } 2011}$ & Hematopoietic & $\begin{array}{c}\mathrm{CD} 34+\mathrm{OCN}+ \\
\mathrm{ALP}+\end{array}$ & $\begin{array}{l}\text { Tang et al., } \\
2019 \text { (58) }\end{array}$ & $\begin{array}{c}\text { Non- } \\
\text { hematopoietic }\end{array}$ & $\begin{array}{l}\text { CD73+ CD90+ } \\
\text { CD105+ CD34- } \\
\text { CD45- }\end{array}$ \\
\hline $\begin{array}{l}\text { Dalle Carbonare } \\
\text { et al., } 2009 \text { (56) }\end{array}$ & Non-hematopoietic & $\begin{array}{l}\text { CD45- CD14- } \\
\text { CD34 low }\end{array}$ & $\begin{array}{c}\text { Dalle } \\
\text { Carbonare et } \\
\text { al., } 2017^{(59)}\end{array}$ & $\begin{array}{c}\text { Non- } \\
\text { hematopoietic }\end{array}$ & $\begin{array}{l}\text { CD45- CD14- } \\
\text { CD34low }\end{array}$ \\
\hline $\begin{array}{l}\text { Undale et al., } \\
2010 \text { (14) }\end{array}$ & Non-hematopoietic & Lin- ALP+ & $\begin{array}{l}\text { Peris et al., } \\
2013^{(60)}\end{array}$ & Hematopoietic & $\begin{array}{c}\text { CD34+ CD133+ } \\
\text { ALP+ OCN+ } \\
\text { Stro1+ VEGFR+ }\end{array}$ \\
\hline$\underset{\text { (57) }}{\text { Pirro et al., } 2010}$ & Hematopoietic & $\begin{array}{c}\mathrm{CD} 34+\mathrm{OCN}+ \\
\mathrm{ALP}+\end{array}$ & $\begin{array}{l}\text { Pasqualini et } \\
\text { al., } 2019^{(61)}\end{array}$ & Hematopoietic & $\begin{array}{c}\text { CD34+ OCN+ } \\
\text { ALP+ }\end{array}$ \\
\hline
\end{tabular}

\section{Secondary Osteoporosis}

\begin{tabular}{|c|c|c|c|c|c|}
\hline$\underset{\text { (62) }}{\text { Pirro et al., } 2012}$ & Hematopoietic & $\begin{array}{c}\mathrm{CD} 34+\mathrm{OCN}+ \\
\mathrm{ALP}+\end{array}$ & $\begin{array}{l}\text { Rubin et al., } \\
2010 \text { (23) }\end{array}$ & Hematopoietic & CD34+ CD146+ \\
\hline $\begin{array}{c}\text { Manavalan et al., } \\
2012(22)\end{array}$ & Unknown & CD146+ OCN+ & & & \\
\hline \multicolumn{6}{|c|}{ Frailty } \\
\hline $\begin{array}{l}\text { Gunawardene et } \\
\text { al., } 2015^{(63)}\end{array}$ & Hematopoietic & $\mathrm{CD} 45+\mathrm{OCN}+$ & $\begin{array}{l}\text { Al Saedi et al., } \\
2017 \text { (65) }\end{array}$ & Hematopoietic & $\mathrm{CD} 45+\mathrm{OCN}+$ \\
\hline
\end{tabular}

This article is protected by copyright. All rights reserved. 
Table 2. Summary of studies surrounding COP cells in states of bone loss. ALP: Alkaline Phosphatase, OCN: Osteocalcin, Lin: Lineage, VEGFR: Vascular Endothelial Growth Factor Receptor

There are several studies on the role of COP cells in primary osteoporosis, some with counterintuitive results. Logically, it could be assumed that osteoporosis might be characterized by a decreased number of COP cells, however a number of studies have shown the opposite. In three studies of postmenopausal osteoporosis, it was found that there were increased numbers of COP cells in the peripheral circulation, ${ }^{(14,55-57)}$ however they had an altered profile of differentiation, with down-regulation of the osteogenic genes RUNX2, SPARC, Sp7 and COL1A1, ${ }^{(56)}$ an altered OPG: nuclear factor kappa- $\beta$ ligand (RANKL) ratio, ${ }^{(14,56)}$ and an altered pattern of marker expression, with elevated markers of more immature stem cells. ${ }^{(14,57)}$ These changes were consistent in both the hematopoietic, and non-hematopoietic cell populations. Interestingly, some studies have also found that the non-hematopoietic population showed increased expression of RANKL in patients with osteoporosis, potentially suggesting that non-hematopoietic COP cells may also have a role in osteoclastogenesis and regulation of resorption, similar to osteoblasts. ${ }^{(14,56)}$ All of these changes are consistent with a decrease in the capacity for osteoblastic differentiation and osteogenesis, suggesting that this may be an additional underlying mechanism for the disease.

This article is protected by copyright. All rights reserved. 
A small number of studies have also investigated the effects of common osteoporosis treatments, both pharmaceutical and adjunctive. The parathyroid hormone analogue teriparatide is a commonly used anabolic medication, and its use has been shown to have an effect on COP cells in osteoporotic women. 54 participants were administered either teriparatide or a bisphosphonate for 12 months, and assessed for COP cell number, alongside densitometric analysis. Teriparatide treatment caused a significant increase in non-hematopoietic COP cells at one month, a change which was sustained throughout the study. Intermittent administration of alendronate also increased the osteogenic capacity of the COP cells in vitro, with increased expression of ALP and osteogenic genes and calcium deposition. ${ }^{(58)}$ Other bisphosphonates have also been evaluated for their effects on COP cells. In another study, zoledronate treatment increased the osteogenic differentiation capacity of COP cells. 22 patients with postmenopausal osteoporosis who began taking zoledronate were followed over 12 months, with analysis of COP cells performed at baseline, 6 and 12 months. Over 12 months of treatment there was an increase in the expression of osteogenic genes such as SPARC and RUNX2, which correlated to changes in $B M D$, indicating that the antiresorptive medication has a pro-osteogenic effect on COP cells. ${ }^{(59)}$ Conversely, a study on risedronate, another bisphosphonate medication found the opposite response. Treatment with risedronate over 4-months had the overall effect of decreasing the expression of OCN and ALP in COP cells. ${ }^{(60)}$ These discrepancies could be due to a number of reasons, including different cell lineages studied, with the zoledronate study investigating non-hematopoietic COP cells and the latter study CD34+ cells. It is also possible

This article is protected by copyright. All rights reserved. 
that the two different bisphosphonates have different effects outside their primary target (the osteoclast), even though they both belong to the same class of drug.

Another study investigated the impacts of weight bearing exercise on COP cells, in women suffering postmenopausal osteoporosis. After three months of weight bearing and resistance exercise, the number of cells expressing either CD34 and OCN or ALP and OCN was shown to increase. Interestingly, there was also a correlation found between COP cell number and muscle strength, perhaps indicating some level of cross-talk between muscle and bone. ${ }^{(61)}$ A greater degree of arterial stiffening has also shown to be associated with the increase in COP cell numbers, possibly indicating a mechanistic link between osteoporosis and vascular disease. ${ }^{(55)}$

Interestingly, the association between COP cell numbers appears to be different in secondary osteoporosis. In osteoporosis secondary to diabetes, thyroid and parathyroid disease, COP cell numbers have been shown to decrease. This has been shown in thyroid disease with a positive correlation between free thyroid hormone levels, COP cell number and $\mathrm{BMD},{ }^{(62)}$ suggesting a role for thyroid function in COP cell biology, a logical connection given the well documented incidence of osteoporosis in hypothyroidism. The role of parathyroid function in COP cell behavior has also been studied. Administering parathyroid hormone (PTH) to patients with hypoparathyroidism was shown to cause a 3 -fold increase in the number of COP cells, and caused a decrease in the expression of the early stem cell

This article is protected by copyright. All rights reserved. 
markers CD34 and CD146, suggesting an increase in the maturation of the cells. These changes also correlated with biochemical and histomorphometric parameters of bone formation, indicating a potential functional effect of the changes measured in COP cells. ${ }^{(23)}$

Following the theme of secondary osteoporosis, COP cells have also been implicated in type 2 diabetes mellitus (T2DM)-associated BMD loss. 18 postmenopausal women with T2DM were compared to 27 age matched, non-diabetic controls. The association of lower numbers of COP cells remained consistent with other studies of secondary osteoporosis, and expression of CD146 was increased, suggesting a decreased level of maturation in the cells. It was also shown that there is down-regulation in the expression of the $R U N X 2$ gene in the COP cells isolated from these patients, both suggesting a decrease in osteogenesis, which was consistent with assessment of histomorphometric indices of bone formation including bone formation rate, mineralizing surface and osteoblast surface. ${ }^{(22)}$

Osteoporosis is also a key component in the geriatric syndrome of frailty, alongside decreases in other areas of physical and cognitive function. Given the important musculoskeletal effects of the syndrome, mesenchymal precursors including COP cells have been investigated by a small number of studies as a unifying mechanism for this complex condition. In a study of community-dwelling older adults who were non-frail, pre-frail or frail it was shown that lower numbers of COP cells correlated with prevalent frailty and disability. ${ }^{(63)}$ Another study identified the expression of the inner nuclear envelope lamin-A

This article is protected by copyright. All rights reserved. 
in COP cells as a potential biomarker of frailty, with frail individuals having $60 \%$ lower expression of the marker than non-frail and pre-frail patients. Lamin A is a key protein involved in cell division and proliferation, ${ }^{(64)}$ and a decrease in its expression was hypothesized to contribute to reduced tissue regeneration leading to frailty. ${ }^{(65)}$

COP cells appear to be associated with osteoporosis and frailty, however more research is needed to fully understand their role. The observed differences in their behaviour between primary and secondary osteoporosis is intriguing, suggestive of multiple underlying mechanisms at play, however what these may be remains unknown. It is also as yet unclear as to whether the changes in COP cells behaviour are mechanistically linked to the decreases in bone density, or if it is simply a related sign of a secondary mechanism impacting both.

\section{COP cells: future prospects in clinical utility}

The evidence presented above assists to place COP cells within the clinical landscape, as far as their ability to cause or influence pathological processes. However, their utility for clinical use is so far completely untapped, and with further research they may play a role in the diagnosis, risk stratification, and management of the conditions discussed above, and potentially many more.

This article is protected by copyright. All rights reserved. 
A common theme of a number of the conditions identified above, is the lack of a feasible, non-invasive, and sensitive and specific biomarker, which allows for the early detection and monitoring of disease. Based on their relationship with a wide range of diseases across a number of physiological systems and ease of retrieval, COP cells could be a potential candidate for a biomarker in this setting. Preliminary evidence has already validated a consistent 'normal' baseline for range across the lifespan, a crucial step in biomarker evaluation. ${ }^{(17)}$ Some preliminary data has already explored their potential in this respect.

The identification of a biomarker that allows for early detection of osteoporosis and frailty is the focus of widespread research. Candidates such as markers of inflammation or bone turnover have proven difficult to implement, as they are not only associated with advancing frailty or bone loss, but with aging itself. COP cell number ${ }^{(63)}$ and expression of lamin A in COP cells ${ }^{(65)}$ have been shown in preliminary studies to have diagnostic value as a biomarker, and are simple and cost effective to use, with the required equipment already in place at most commercial laboratories. Similar associations have been found in vascular calcification, with COP cell number associating with both the presence and the severity of the disease. ${ }^{(50)}$ While their preliminary associations with disease states are promising, their potential for use as a biomarker in any condition is limited by lack of consistent research into their behaviour and identity. Interestingly, a recent study has identified a relationship between $\mathrm{CD} 34-/ \mathrm{OCN}+\mathrm{COP}$ cells, and bone metastasis in patients with breast cancer. They identified that patients with high metastatic burden had greater numbers of COP cells, and

This article is protected by copyright. All rights reserved. 
importantly, that their percentage predicted 18-month bone metastasis development and progression. ${ }^{(66)}$ While the study was small, these findings suggest exciting potential for clinical utility in malignant diseases with common skeletal metastasis. Longitudinal studies with standard criteria for identification, in both healthy individuals and patients with target diseases are required to validate diagnostic and prognostic cut off points, as well as identify their predictive value, test inter- and intra-rater reliability and consistency.

Another area of clinical exploitation that is gathering significant international interest is in cellular therapies. Both autologous and exogenous MPCs have successfully been used to treat a wide range of diseases - from acute myocardial infarction and heart failure, ${ }^{(67,68)}$ to frailty, ${ }^{(69)}$ however, a number of challenges has slowed progress in this area. Firstly, MPCs are difficult and invasive to harvest, requiring bone marrow aspiration, and once harvested can be challenging to expand to therapeutic numbers - particularly in populations who are likely to require the treatment such as older or unwell persons. ${ }^{(70)}$ COP cells have the potential to circumvent a number of these issues, as they are readily available in the peripheral circulation, and although their numbers are low, larger volumes of blood can be gained than bone marrow without detrimental effects, even in older persons. Similarly to MPCs obtained from other sources, they have the capacity for in vitro expansion and differentiation, however there are conflicting reports on how these parameters compare to that of the bone marrow cells. They have been used in animal models to treat fractures, showing beneficial effects when injected into the site of bone injury. ${ }^{(35,37)}$ However despite

This article is protected by copyright. All rights reserved. 
these favorable points, there is still a vast amount of missing information surrounding COP cells, that would be required to utilize them clinically. Firstly, the therapeutic effects of MPC treatments, are thought to be due in a large part to their humoral effects, rather than their ability to regenerate tissue. MPCs secrete a range of potent growth factors and immunomodulatory cyto- and chemokines, which are able to stimulate the healing of local tissues. ${ }^{(71)}$ As yet, no studies have explored the secretory capacity of COP cells of any form, leaving it unclear as to whether they share this capacity. MPCs also have the beneficial ability to largely avoid causing immune reactions in allogenic hosts, (though they are no longer thought to be truly "immune-evasive", particularly with repeat application)(72) allowing for widespread, and importantly, low risk use. Again, this is largely yet to be investigated in COP cells, with no human studies investigating either their immune profile, or their tolerability for infusion, in autologous or allogenic applications. One study did apply human COP cells to a mouse model of fracture with success, reporting no adverse sideeffects, and improved fracture healing, ${ }^{(42)}$ however far more safety evaluation is required for their therapeutic use.

\section{Conclusions}

This review provides insight into the complexities of COP cell behavior in disease states, and some common themes can be drawn. It is consistently shown that in states of physiological and pathological bone formation such as vascular calcification, heterotopic ossification, and fracture repair COP cells mobilize and migrate to the site of osteogenesis. The mechanisms

This article is protected by copyright. All rights reserved. 
underlying these processes are unknown, however, alterations in BMP expression in tissues may play a role. It is also likely that the CXCR4/CXCL12 axis ${ }^{(19)}$ is a key migration pathway, however there are likely others, such as TGF $\beta$ that are also important. ${ }^{(53)}$ Once they have migrated to the site of bone formation, there role is less clear, however overall, the appear to enhance bone formation. Whether this is by direct differentiation to osteoblasts and subsequent mineralization, or by factor secretion, remains unknown.

In states of bone loss, such as osteoporosis and frailty, the behaviour of COP cells seems more complex. In primary, postmenopausal osteoporosis, counterintuitively, COP cell numbers appear to increase, but their capacity for osteogenesis and their maturation are diminished. It is unknown as to whether this is a mechanism underpinning the disease, or another expression of a more complex change, causing a system wide decrease in bone forming capacity, affecting both COP cells and the bones themselves. However, in thyroid, parathyroid or type 2 diabetes linked secondary osteoporosis, COP cell numbers decline, with an accompanying decrease in osteogenic markers. This contradiction is likely reflective of different mechanisms leading to primary and secondary osteoporosis impacting the COP cells, however the exact physiologies at play are still not known.

More broadly, a number of key answers remain elusive. Importantly, lack of a cohesive schema for COP cell characterization has led to a confusing body of literature, with a number of different cell populations identified across different pathologies. It is unclear 
what the specific roles and functions of the hematopoietic versus non-hematopoietic COP cell populations are, and how they relate to one another. There are also a number of studies where no unifying markers were studied, instead only showing markers of bone formation such as OCN. For the field to progress, a common methodology of isolation, phenotypic characterization, and nomenclature should be developed to allow more reliable conclusions to be drawn between studies. Thorough studies identifying and comparing the behaviors of these different subgroups of COP cells are also required to identify which are the most clinically relevant in each specific area. It is also uncertain what the impact of COP cells truly is, particularly given their relative scarcity in the circulation. As the majority of the evidence surrounding COP cells is observational and correlational, their true role in the pathogenesis, progression, or resolution of any of the pathologies or physiologies discussed above is unclear. To combat this, mechanistic studies are required to identify whether the demonstrated alterations in COP cell behaviour are causative, or only an indicator of an underlying disease process. This will also allow for a broader understanding of their potential for use in a clinical setting for treatment, prognosis, or management of disease.

COP cells are an exciting area of exploration in the musculoskeletal field, however, there remain far more questions than answers regarding their physiology, significance, and potential for use in a clinical setting. Future research should focus on detailed biological assessment of the different populations of cells, and their baseline biological behaviour, to allow for effective and meaningful translation into clinical use in the future. 


\section{Acknowledgements}

This research is supported through an Australian Government Research Training Program (RTP) Scholarship and Stipend to JF, seed grants from the Australian Institute for Musculoskeletal Science (AIMSS) to JF and GD, and the Robert and Alene Kogod Professorship in Geriatric Medicine to RJP. MK received grants from the NovoNordisk foundation (NNF170C00029290 and NNF150C0016284).

\section{Conflict of Interest}

No conflict of interest to declare.

\section{Author Contributions}

JF: Conceptualization; data curation; formal analysis; investigation; methodology; validation; visualization; writing-original draft; writing-review and editing.

MK: Investigation; methodology; supervision; writing-review and editing.

RJP: Investigation; methodology; supervision; writing-review and editing.

GD: Conceptualization; methodology; project administration; resources; supervision; writing-review and editing.

Figure Legends

This article is protected by copyright. All rights reserved. 
Figure 1. Summary depiction of currently known biology of COP cells. MPC: Mesenchymal stem and progenitor cell, HSC: Hematopoietic stem cell, CXCR4: C-X-C chemokine receptor 4, CXCL12: : C-X-C motif chemokine 12.

Figure 2. Summary diagram of known COP cell behaviour in states of pathological bone formation. BM: Bone marrow, CXCR4: C-X-C chemokine receptor 4, CXCL12: : C-X-C motif chemokine 12, BMP2: Bone morphogenetic protein 2, FOP: Fibrodysplasia Ossificans Progressiva, HO: Heterotopic ossification, OCN: Osteocalcin, ALP: Alkaline Phosphatase, Col1: Type one collagen.

Figure 3. Summary diagram of known COP cell behaviour in states of pathological bone loss. RANKL: Receptor activator of nuclear factor kappa- $\beta$ ligand.

This article is protected by copyright. All rights reserved. 


\section{References}

1. Kuwana $\mathrm{M}$, Okazaki $\mathrm{Y}$, Kodama $\mathrm{H}$, Izumi $\mathrm{K}$, Yasuoka $\mathrm{H}$, Ogawa $\mathrm{Y}$, et al. Human circulating $\mathrm{CD} 14+$ monocytes as a source of progenitors that exhibit mesenchymal cell differentiation. J Leukoc Biol. Nov 2003;74(5):833-45. Epub 2003/09/10.

2. Kuznetsov SA, Mankani MH, Gronthos S, Satomura K, Bianco P, Robey PG. Circulating skeletal stem cells. The Journal of cell biology. 2001;153(5):1133-40.

3. Feehan J, Nurgali K, Apostolopoulos V, Al Saedi A, Duque G. Circulating osteogenic precursor cells: Building bone from blood. EBioMedicine. 2018.

4. Dominici M, Le Blanc K, Mueller I, Slaper-Cortenbach I, Marini F, Krause D, et al. Minimal criteria for defining multipotent mesenchymal stromal cells. The International Society for Cellular Therapy position statement. Cytotherapy. 2006;8(4):315-7. Epub 2006/08/23.

5. Friedenstein AJ, Petrakova KV, Kurolesova Al, Frolova GP. Heterotopic transplants of bone marrow. Transplantation. 1968;6(2):230-47.

6. Fernandez M, Simon V, Herrera G, Cao C, Favero H, Minguell J. Detection of stromal cells in peripheral blood progenitor cell collections from breast cancer patients. Bone marrow transplantation. 1997;20(4):265.

7. Zvaifler NJ, Marinova-Mutafchieva L, Adams G, Edwards CJ, Moss J, Burger JA, et al. Mesenchymal precursor cells in the blood of normal individuals. Arthritis Research \& Therapy. 2000;2(6):477.

8. Eghbali-Fatourechi GZ, Lamsam J, Fraser D, Nagel D, Riggs BL, Khosla S. Circulating osteoblast-lineage cells in humans. New England Journal of Medicine. 2005;352(19):195966.

9. Long MW, Robinson J, Ashcraft E, Mann KG. Regulation of human bone marrow-derived osteoprogenitor cells by osteogenic growth factors. The Journal of clinical investigation. 1995;95(2):881-7.

10. Long MW, Williams JL, Mann KG. Expression of human bone-related proteins in the hematopoietic microenvironment. The Journal of clinical investigation. 1990;86(5):1387-95.

11. Egan KP, Kim JH, Mohler ER, 3rd, Pignolo RJ. Role for circulating osteogenic precursor cells in aortic valvular disease. Arterioscler Thromb Vasc Biol. Dec 2011;31(12):2965-71. Epub 2011/09/10.

12. Alm JJ, Koivu HM, Heino TJ, Hentunen TA, Laitinen S, Aro HT. Circulating plastic adherent mesenchymal stem cells in aged hip fracture patients. J Orthop Res. Dec 2010;28(12):163442. Epub 2010/06/12.

13. Suda RK, Billings PC, Egan KP, Kim JH, McCarrick-Walmsley R, Glaser DL, et al. Circulating osteogenic precursor cells in heterotopic bone formation. Stem Cells. Sep 2009;27(9):220919. Epub 2009/06/13.

14. Undale A, Srinivasan B, Drake M, McCready L, Atkinson E, Peterson J, et al. Circulating osteogenic cells: characterization and relationship to rates of bone loss in postmenopausal women. Bone. Jul 2010;47(1):83-92. Epub 2010/04/07.

This article is protected by copyright. All rights reserved. 
15. Kumagai K, Vasanji A, Drazba JA, Butler RS, Muschler GF. Circulating cells with osteogenic potential are physiologically mobilized into the fracture healing site in the parabiotic mice model. J Orthop Res. Feb 2008;26(2):165-75. Epub 2007/08/31.

16. Boban I, Barisic-Dujmovic T, Clark SH. Parabiosis model does not show presence of circulating osteoprogenitor cells. Genesis. Mar 2010;48(3):171-82. Epub 2010/02/04.

17. Gunawardene P, Al Saedi A, Singh L, Bermeo S, Vogrin S, Phu S, et al. Age, gender, and percentage of circulating osteoprogenitor (COP) cells: The COP Study. Exp Gerontol. Oct 1 2017;96:68-72. Epub 2017/06/11.

18. Otsuru S, Overholt KM, Olson TS, Hofmann TJ, Guess AJ, Velazquez VM, et al. Hematopoietic derived cells do not contribute to osteogenesis as osteoblasts. Bone. Jan 2017;94:1-9. Epub 2016/11/03.

19. Otsuru S, Tamai K, Yamazaki T, Yoshikawa H, Kaneda Y. Circulating bone marrow-derived osteoblast progenitor cells are recruited to the bone-forming site by the CXCR4/stromal cellderived factor-1 pathway. Stem Cells. Jan 2008;26(1):223-34. Epub 2007/10/13.

20. Hong HS, Lee J, Lee E, Kwon YS, Lee $E$, Ahn W, et al. A new role of substance $P$ as an injuryinducible messenger for mobilization of CD29(+) stromal-like cells. Nat Med. Apr 2009;15(4):425-35. Epub 2009/03/10.

21. Rochefort GY, Delorme B, Lopez A, Herault O, Bonnet P, Charbord P, et al. Multipotential mesenchymal stem cells are mobilized into peripheral blood by hypoxia. Stem Cells. Oct 2006;24(10):2202-8. Epub 2006/06/17.

22. Manavalan JS, Cremers S, Dempster DW, Zhou H, Dworakowski E, Kode A, et al. Circulating osteogenic precursor cells in type 2 diabetes mellitus. J Clin Endocrinol Metab. Sep 2012;97(9):3240-50. Epub 2012/06/29.

23. Rubin MR, Manavalan JS, Dempster DW, Shah J, Cremers S, Kousteni S, et al. Parathyroid hormone stimulates circulating osteogenic cells in hypoparathyroidism. J Clin Endocrinol Metab. Jan 2011;96(1):176-86. Epub 2010/10/01.

24. Hossain A, Jung LK. Expression of bone specific alkaline phosphatase on human B cells (86.18). The Journal of Immunology. 2007;178(1 Supplement):S127-S.

25. Heinemann DE, Siggelkow H, Ponce LM, Viereck V, Wiese KG, Peters JH. Alkaline Phosphatase Expression during Monocyte Differentiation Overlapping markers as a link between monocytic cells, dendritic cells, osteoclasts and osteoblasts. Immunobiology. 2000;202(1):68-81.

26. Kumagai $K$, Takeuchi $R$, Ishikawa $H$, Yamaguchi $Y$, Fujisawa $T$, Kuniya $T$, et al. Low-intensity pulsed ultrasound accelerates fracture healing by stimulation of recruitment of both local and circulating osteogenic progenitors. J Orthop Res. Sep 2012;30(9):1516-21. Epub 2012/03/16.

27. Iwakura T, Lee SY, Miwa M, Sakai Y, Niikura T, Oe K, et al. Analysis of circulating mesenchymal progenitor cells in arterial and venous blood after fracture. J Tissue Eng Regen Med. Jun 2013;7(6):501-4. Epub 2012/02/18.

28. D'Amelio P, Cristofaro MA, Grimaldi A, Ravazzoli M, Pluviano F, Grosso E, et al. The role of circulating bone cell precursors in fracture healing. Calcif Tissue Int. Jun 2010;86(6):463-9. Epub 2010/04/15.

29. Kingsley DM. The TGF-beta superfamily: new members, new receptors, and new genetic tests of function in different organisms. Genes \& development. 1994;8(2):133-46.

This article is protected by copyright. All rights reserved. 
30. Wahl SM, Wen J, Moutsopoulos N. TGF- $\beta$ : a mobile purveyor of immune privilege. Immunological reviews. 2006;213(1):213-27.

31. Sicco CL, Reverberi D, Villa F, Pfeffer U, Quarto R, Cancedda R, et al. Circulating healing $(\mathrm{CH})$ cells expressing BST2 are functionally activated by the injury-regulated systemic factor HGFA. Stem cell research \& therapy. 2018;9(1):300.

32. Ritz U, Spies V, Mehling I, Gruszka D, Rommens PM, Hofmann A. Mobilization of CD34+progenitor cells in patients with severe trauma. PLoS One. 2014;9(5):e97369. Epub 2014/05/16.

33. Kelly RR, McDonald LT, Pellegrini VD, Cray JJ, Larue AC. Identification of circulating murine CD34+ OCN+ cells. Cytotherapy. 2018.

34. Schemitsch EH. Size Matters: Defining Critical in Bone Defect Size! Journal of orthopaedic trauma. 2017;31:S20-S2.

35. Wan C, He Q, Li G. Allogenic peripheral blood derived mesenchymal stem cells (MSCs) enhance bone regeneration in rabbit ulna critical-sized bone defect model. Journal of orthopaedic research. 2006;24(4):610-8.

36. Matsumoto $T$, Kawamoto A, Kuroda R, Ishikawa M, Mifune $Y$, Iwasaki $H$, et al. Therapeutic potential of vasculogenesis and osteogenesis promoted by peripheral blood CD34-positive cells for functional bone healing. Am J Pathol. Oct 2006;169(4):1440-57. Epub 2006/09/28.

37. Mifune $\mathrm{Y}$, Matsumoto $\mathrm{T}$, Kawamoto A, Kuroda R, Shoji T, Iwasaki $\mathrm{H}$, et al. Local delivery of granulocyte colony stimulating factor-mobilized CD34-positive progenitor cells using bioscaffold for modality of unhealing bone fracture. Stem Cells. Jun 2008;26(6):1395-405. Epub 2008/04/05.

38. Gnecchi M, Zhang Z, Ni A, Dzau VJ. Paracrine mechanisms in adult stem cell signaling and therapy. Circulation research. 2008;103(11):1204-19.

39. Yellowley C. CXCL12/CXCR4 signaling and other recruitment and homing pathways in fracture repair. Bonekey Rep. 2013;2:300-.

40. Ono T, Takayanagi H. Osteoimmunology in bone fracture healing. Current osteoporosis reports. 2017;15(4):367-75.

41. Shore EM, Xu M, Feldman GJ, Fenstermacher DA, Cho T-J, Choi IH, et al. A recurrent mutation in the BMP type I receptor ACVR1 causes inherited and sporadic fibrodysplasia ossificans progressiva. Nature genetics. 2006;38(5):525-7.

42. Yang HS, Kim GH, La WG, Bhang SH, Lee TJ, Lee JH, et al. Enhancement of human peripheral blood mononuclear cell transplantation-mediated bone formation. Cell Transplant. 2011;20(9):1445-52. Epub 2011/03/08.

43. Otsuru S, Tamai K, Yamazaki T, Yoshikawa H, Kaneda Y. Bone marrow-derived osteoblast progenitor cells in circulating blood contribute to ectopic bone formation in mice. Biochem Biophys Res Commun. Mar 9 2007;354(2):453-8. Epub 2007/01/24.

44. Egan KP, Duque G, Keenan MA, Pignolo RJ. Circulating osteogentic precursor cells in nonhereditary heterotopic ossification. Bone. Jan 3 2018. Epub 2018/01/07.

45. Foley KL, Hebela N, Keenan MA, Pignolo RJ. Histopathology of periarticular non-hereditary heterotopic ossification. Bone. 2017.

46. Kaplan FS, Glaser DL, Shore EM, Pignolo RJ, Xu M, Zhang Y, et al. Hematopoietic stem-cell contribution to ectopic skeletogenesis. JBJS. 2007;89(2):347-57.

This article is protected by copyright. All rights reserved. 
47. Cannata-Andía JB, Rodríguez-García M, Carrillo-López N, Naves-Díaz M, Díaz-López B. Vascular calcifications: pathogenesis, management, and impact on clinical outcomes. Journal of the American Society of Nephrology. 2006;17(12 suppl 3):S267-S73.

48. Thompson B, Towler DA. Arterial calcification and bone physiology: role of the bonevascular axis. Nature Reviews Endocrinology. 2012;8(9):529.

49. Fadini GP, Albiero M, Menegazzo L, Boscaro E, de Kreutzenberg SV, Agostini C, et al. Widespread increase in myeloid calcifying cells contributes to ectopic vascular calcification in type 2 diabetes. Circulation Research. 2011:CIRCRESAHA. 110.234088.

50. Pal SN, Rush C, Parr A, Van Campenhout A, Golledge J. Osteocalcin positive mononuclear cells are associated with the severity of aortic calcification. Atherosclerosis. May 2010;210(1):88-93. Epub 2009/12/17.

51. Pal SN, Clancy P, Golledge J. Circulating Concentrations of Stem-Cell-Mobilizing Cytokines Are Associated With Levels of Osteoprogenitor Cells and Aortic Calcification Severity. Circulation Journal. 2011;75(5):1227-34.

52. Takahashi K, Satoh M, Takahashi Y, Osaki T, Nasu T, Tamada M, et al. Dysregulation of ossification-related miRNAs in circulating osteogenic progenitor cells obtained from patients with aortic stenosis. Clin Sci (Lond). Jul 1 2016;130(13):1115-24. Epub 2016/04/30.

53. Wang W, Li C, Pang L, Shi C, Guo F, Chen A, et al. Mesenchymal stem cells recruited by active TGFbeta contribute to osteogenic vascular calcification. Stem Cells Dev. Jun 15 2014;23(12):1392-404. Epub 2014/02/12.

54. Sözen T, Özışık L, Başaran NÇ. An overview and management of osteoporosis. European journal of rheumatology. 2017;4(1):46.

55. Pirro M, Schillaci G, Mannarino MR, Scarponi AM, Manfredelli MR, Callarelli L, et al. Circulating immature osteoprogenitor cells and arterial stiffening in postmenopausal osteoporosis. Nutr Metab Cardiovasc Dis. Sep 2011;21(9):636-42. Epub 2010/06/18.

56. Dalle Carbonare L, Valenti MT, Zanatta M, Donatelli L, Lo Cascio V. Circulating mesenchymal stem cells with abnormal osteogenic differentiation in patients with osteoporosis. Arthritis Rheum. Nov 2009;60(11):3356-65. Epub 2009/10/31.

57. Pirro M, Leli C, Fabbriciani G, Manfredelli MR, Callarelli L, Bagaglia F, et al. Association between circulating osteoprogenitor cell numbers and bone mineral density in postmenopausal osteoporosis. Osteoporos Int. Feb 2010;21(2):297-306. Epub 2009/06/02.

58. Tang Y, Xia H, Kang L, Sun Q, Su Z, Hao C, et al. Effects of Intermittent Parathyroid Hormone 1-34 Administration on Circulating Mesenchymal Stem Cells in Postmenopausal Osteoporotic Women. Med Sci Monit. Jan 8 2019;25:259-68. Epub 2019/01/09.

59. Dalle Carbonare L, Mottes M, Malerba G, Mori A, Zaninotto M, Plebani M, et al. Enhanced Osteogenic Differentiation in Zoledronate-Treated Osteoporotic Patients. Int J Mol Sci. Jun 13 2017;18(6). Epub 2017/06/14.

60. Peris P, Atkinson EJ, GossI M, Kane TL, McCready LK, Lerman A, et al. Effects of bisphosphonate treatment on circulating osteogenic endothelial progenitor cells in postmenopausal women. Mayo Clin Proc. Jan 2013;88(1):46-55. Epub 2012/12/12.

61. Pasqualini L, Ministrini S, Lombardini R, Bagaglia F, Paltriccia R, Pippi R, et al. Effects of a 3month weight-bearing and resistance exercise training on circulating osteogenic cells and bone formation markers in postmenopausal women with low bone mass. Osteoporos Int. Apr 2019;30(4):797-806. Epub 2019/02/28.

This article is protected by copyright. All rights reserved. 
62. Pirro M, Manfredelli MR, Scarponi AM, Lupattelli G, Bagaglia F, Melis F, et al. Association between thyroid hormone levels, the number of circulating osteoprogenitor cells, and bone mineral density in euthyroid postmenopausal women. Metabolism. Apr 2012;61(4):569-76. Epub 2011/11/15.

63. Gunawardene P, Bermeo S, Vidal C, Al-Saedi A, Chung P, Boersma D, et al. Association between circulating osteogenic progenitor cells and disability and frailty in older persons: the Nepean Osteoporosis and Frailty Study. Journals of Gerontology Series A: Biomedical Sciences and Medical Sciences. 2015;71(9):1124-30.

64. Coutinho HDM, Falcão-Silva VS, Gonçalves GF, da Nóbrega RB. Molecular ageing in progeroid syndromes: Hutchinson-Gilford progeria syndrome as a model. Immunity \& Ageing. 2009;6(1):4.

65. Al Saedi A, Gunawardene P, Bermeo S, Vogrin S, Boersma D, Phu S, et al. Lamin A expression in circulating osteoprogenitors as a potential biomarker for frailty: The Nepean Osteoporosis and Frailty (NOF) Study. Exp Gerontol. Dec 1 2017;102:69-75. Epub 2017/12/06.

66. Lee KH, Lee KJ, Kim TY, Hutomo F, Sun HJ, Cheon GJ, et al. Circulating Osteocalcin-Positive Cells as a Novel Diagnostic Biomarker for Bone Metastasis in Breast Cancer Patients. Journal of Bone and Mineral Research. 2020.

67. Jeong H, Yim HW, Park H-J, Cho Y, Hong H, Kim NJ, et al. Mesenchymal Stem Cell Therapy for Ischemic Heart Disease: Systematic Review and Meta-analysis. Int J Stem Cells. 2018;11(1):112.

68. Fan $M$, Huang $\mathrm{Y}$, Chen $Z$, Xia $Y$, Chen $A$, Lu D, et al. Efficacy of mesenchymal stem cell therapy in systolic heart failure: a systematic review and meta-analysis. Stem Cell Research \& Therapy. 2019/05/31 2019;10(1):150.

69. Schulman IH, Balkan W, Hare JM. Mesenchymal Stem Cell Therapy for Aging Frailty. Frontiers in Nutrition. Perspective 2018-November-15 2018;5(108).

70. Lukomska B, Stanaszek L, Zuba-Surma E, Legosz P, Sarzynska S, Drela K. Challenges and Controversies in Human Mesenchymal Stem Cell Therapy. Stem cells international. 2019;2019:9628536-.

71. Harrell CR, Fellabaum C, Jovicic N, Djonov V, Arsenijevic N, Volarevic V. Molecular Mechanisms Responsible for Therapeutic Potential of Mesenchymal Stem Cell-Derived Secretome. Cells. 2019;8(5):467.

72. Lohan P, Treacy O, Griffin MD, Ritter T, Ryan AE. Anti-Donor Immune Responses Elicited by Allogeneic Mesenchymal Stem Cells and Their Extracellular Vesicles: Are We Still Learning? Frontiers in Immunology. Mini Review 2017-November-24 2017;8(1626).

This article is protected by copyright. All rights reserved. 


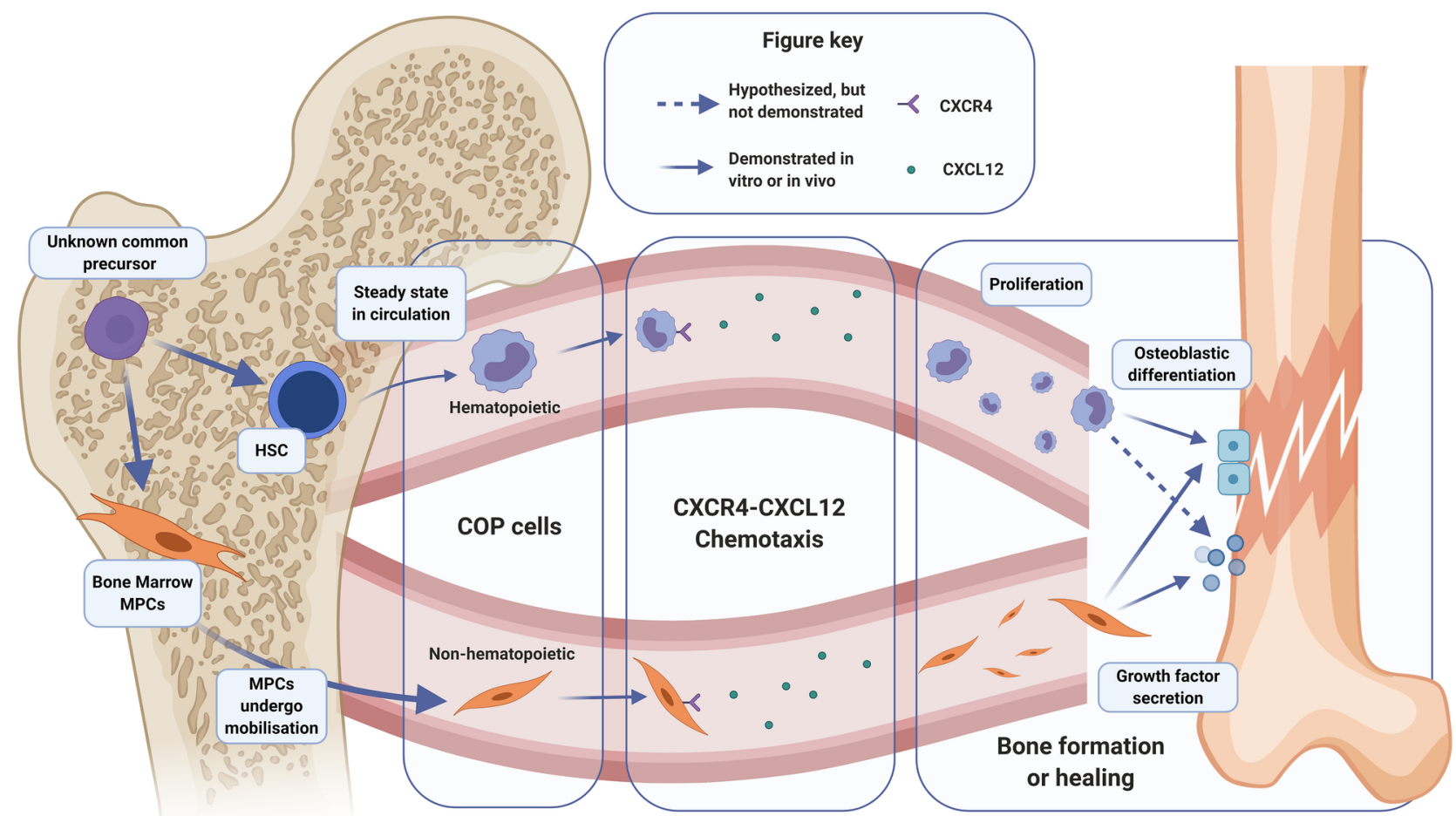

JBMR_4204_Figure 1.tif

This article is protected by copyright. All rights reserved. 


\section{States of anabolism and calcification}
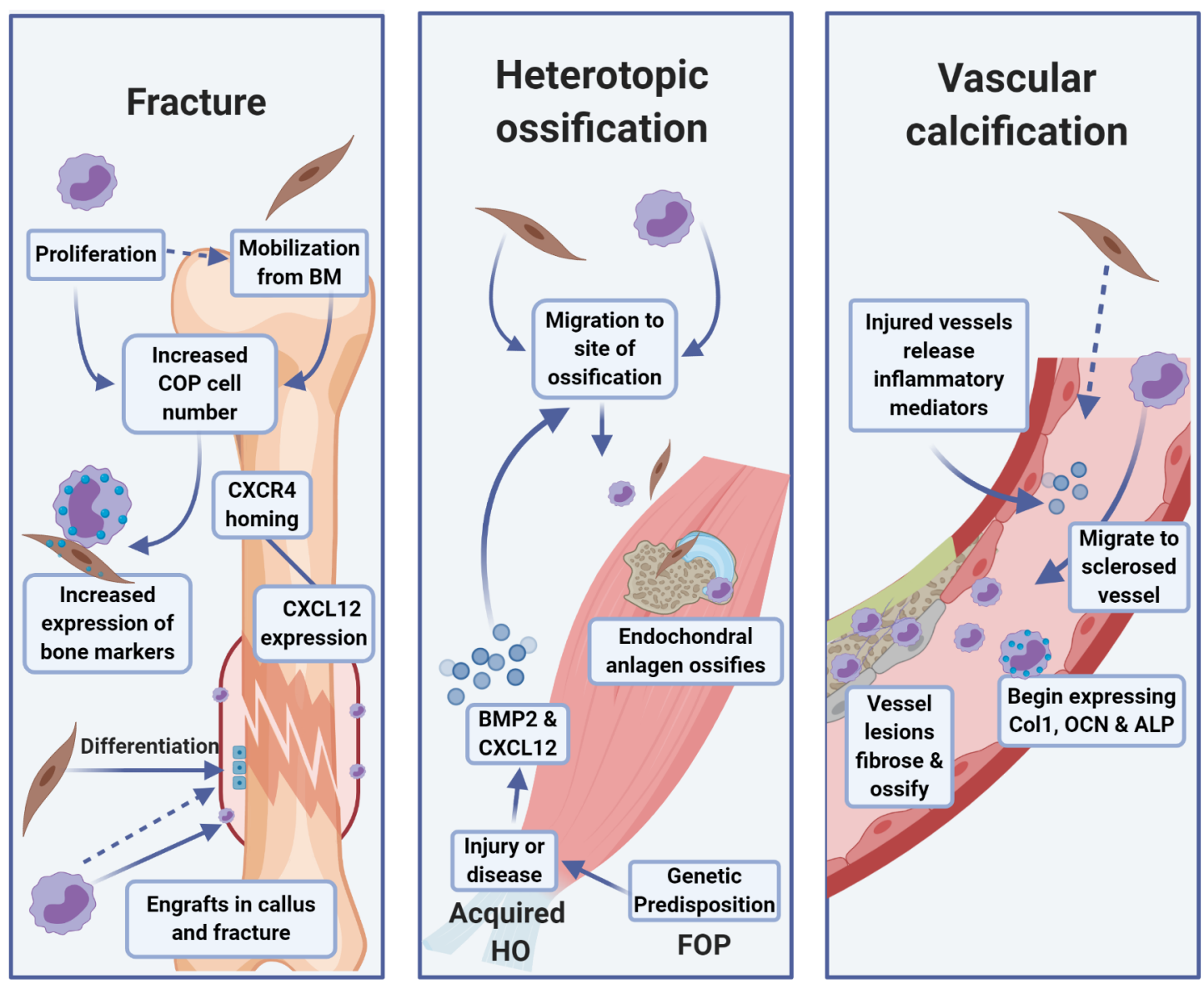

Hematopoietic COP

Non-hematopoietic COP

JBMR_4204_Figure 2.tif

This article is protected by copyright. All rights reserved. 


\section{States of abnormal tissue regeneration}
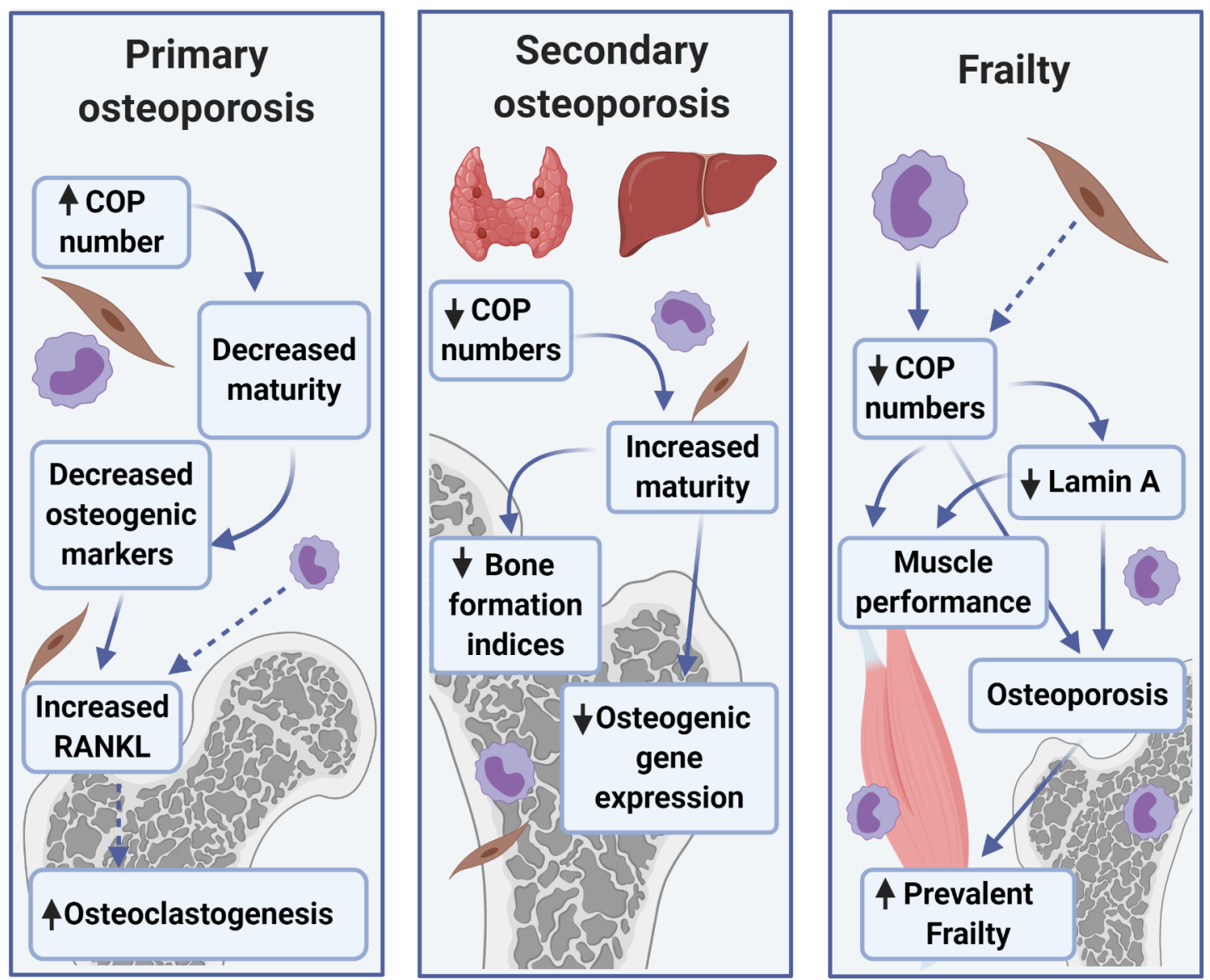

Hematopoietic COP

Non-hematopoietic COP

JBMR_4204_Figure 3.tif

This article is protected by copyright. All rights reserved. 


\section{University Library}

\section{- M M I N E R VA A gateway to Melbourne's research publications}

Minerva Access is the Institutional Repository of The University of Melbourne

Author/s:

Feehan, J;Kassem, M;Pignolo, RJ;Duque, G

Title:

Bone From Blood: Characteristics and Clinical Implications of Circulating Osteogenic Progenitor (COP) Cells

Date:

2021-01

\section{Citation:}

Feehan, J., Kassem, M., Pignolo, R. J. \& Duque, G. (2021). Bone From Blood:

Characteristics and Clinical Implications of Circulating Osteogenic Progenitor (COP) Cells. JOURNAL OF BONE AND MINERAL RESEARCH, 36 (1), pp.12-23. https://doi.org/10.1002/ jbmr.4204.

Persistent Link:

http://hdl.handle.net/11343/276608 